\title{
Productivity of White and Yellow Grain Corns in Campeche, México
}

\author{
Juan Medina-Méndez ${ }^{1 *}$, Jesús Manuel Soto-Rocha ${ }^{1}$, Antonio Villalobos-González ${ }^{1}$, \\ Víctor Hugo Volke-Haller², Joaquín Gómez-Tejero' ${ }^{1}$ \\ ${ }^{1}$ Campo Experimental Edzná, Instituto Nacional de Investigaciones Forestales Agrícolas y Pecuarias, Campeche, México \\ ${ }^{2}$ Postgrado en Edafología, Colegio de Postgraduados, Montecillo, México \\ Email: ${ }^{\star}$ medina.juan@inifap.gob.mx
}

How to cite this paper: Medina-Méndez, J., Soto-Rocha, J.M., Villalobos-González, A., Volke-Haller, V.H. and Gómez-Tejero, J. (2019) Productivity of White and Yellow Grain Corns in Campeche, México. Agricultural Sciences, 10, 1255-1269. https://doi.org/10.4236/as.2019.109093

Received: February 25, 2019

Accepted: September 26, 2019

Published: September 29, 2019

Copyright $\odot 2019$ by author(s) and Scientific Research Publishing Inc. This work is licensed under the Creative Commons Attribution International License (CC BY 4.0).

http://creativecommons.org/licenses/by/4.0/

\begin{abstract}
The present work took place in the central and northern regions of the state of Campeche, Mexico. The grain yield was evaluated in a total of 46 materials, comprising 30 of white grain and 16 of yellow grain. The crop was supplied to a greater extent with rainwater from the months of July to November. The sowing was in trials designed to evaluate grain yield and technology validation lots established for demonstration purposes. To integrate a genetic material into this study, it was a fundamental requirement that it had at least four evaluations considering different locations or years. As a result of the above, it was determined that there are 27 hybrids of white grain and 14 of yellow grain, which constitute options for the producer with which it is possible to obtain yields of 4.1 to $6.0 \mathrm{t}^{\mathrm{h}} \mathrm{ha}^{-1}$ and that can make corn a profitable crop under the current conditions of technology application. Of the white grain hybrids, the group formed by SB-309, DK-395, DK-393, DAS-2382, SP-500, DK-390, P4082W, 9209W, P3966W, SORENTO, JC-25, LUCINO, and $9401 \mathrm{~W}$ was considered as the high productivity stratum, whose average yield is 5.1 to $5.9 \mathrm{t} \cdot \mathrm{ha}^{-1}$. Similarly, in the yellow grain hybrids, the group formed 9107Y, SP-525A, 2B688, DK-7500, P4226A, IMPACT and DK-7088, was considered as the high productivity stratum, whose average yield fluctuated from 5.0 to $5.9 \mathrm{t} \cdot \mathrm{ha}^{-1}$.
\end{abstract}

\section{Keywords}

White and Yellow Maize, Tropics, Arable Soils

\section{Introduction}

Corn in Mexico is a vitally important crop, figures reported in recent years indi- 
cate that in our country about 8 million hectares are cultivated, which produce $100 \%$ of the corn required to cover the domestic demand of the white grain used for the feed of the population. However, as regards yellow corn, there is a large deficit in production, since about 1 million hectares are grown annually, which produce only 10 million tons, while the demand for this grain is 20 million tons per year, which are mainly used in the production of animal feed [1]. In Campeche, corn is cultivated in an area of close to 150,000 hectares, close to $90 \%$ of white grain and only $10 \%$ of yellow grain, and there are 34,872 registered farmers, for whom this crop is an important source of income. The statistical data indicate that corn occupies the first place in the state agricultural production, with a value of $53 \%$ and it is cultivated in different environments, the most important being the rainfed corn system, which is supplied mainly with rain, and in which the sowing takes place in summer, in the months of June to July. Due mainly to the unpredictability of the rains, the high temperature in the growing season and some deficiencies in the technology, the maize that is sown in summer is of low yield, with only 3.3 to $3.7 \mathrm{t} \cdot \mathrm{ha}^{-1}$ [2]. Great part of the area cultivated with corn has machinable soils, that is to say, it is susceptible to work with machinery due to the absence of rocks in its most superficial horizon, and there are at least three types of soil easily distinguishable in the north and center areas, which they make up the region of the entity where the cultivation of corn predominates. These soils are called Luvisols and Vertisols [3]. The seed that is used for the sowing of the maize is mainly of hybrids and varieties of pollination obtained by the own producer. The production of white grain corn dominates over that of yellow grain, but little by little the latter is becoming important because the modality of contract farming is increasingly common among producers. This document was written with the results obtained in the research carried out by INIFAP between 2011 and 2015. The objective of this was to determine the yield of varieties and hybrids of white and yellow corn, to identify the best options and recommend them for farmers' use.

\section{Materials and Methods}

\subsection{Soil and Climate in the Study Area}

The research was carried out on localities with predominantly "Kancab" (Maya), Luvisol ferric; the exceptions were Valle de Quetzalcoatl and the Experimental Site Ezdná, whose soils were "Akalché" and "Yaaxhom" (Maya), which correspond to Vertisol gleyco and Luvisol chromic soils, respectively [3]. The climate in the study locations is tropical rainy A (W) with rain in summer, with an average temperature of $24^{\circ} \mathrm{C}$ to $28^{\circ} \mathrm{C}$ and an average annual rainfall of 900 to 1200 $\mathrm{mm}[4][5]$.

\subsection{Study Locations}

For this research, localities from the northern and central regions of the state of 
Campeche were selected in which the largest area of maize produced in soils worked with machinery is concentrated. The municipalities that comprise these regions were: Calkiní, Hecelchakán, Hopelchén, Tenabo, Campeche and Champotón. The names of the study locations where the performance trials and the demonstration plots were established, as well as their geographical location are indicated in Table 1. As can be seen, the evaluations were carried out in a wide geographic area, but the time quite homogeneous in the type of technological management of the crop. The environmental conditions where the water supply of the plant was $100 \%$ based on rainwater from the summer and autumn seasons.

\subsection{Genetic Material in Evaluation}

In this study, the yield results obtained in 30 white grain and 16 yellow grain hybrids were analyzed (Table 2). These hybrids were selected from a group of 62 cultivars that were evaluated in the state of Campeche, in the period from 2011 to 2015 with the objective of knowing their performance behavior and transferring the results to the producers. The yield data were obtained by sampling carried out in plots of cooperating producers, which the researchers established in order to transfer results to the producers and other users of the technology; as well as performance trials developed for the purpose of research and validation of the behavior of commercial and experimental corn hybrids. In order to achieve greater precision in the recommendations it was decided to select for this study only those hybrids that were evaluated at least four times (four years, or four different locations), which would have the highest number of repetitions in each [6] [7] [8].

\subsection{Technology Applied in Crop Management.}

For the technological management of the crop, the recommendations of the Technological Package published by the National Institute of Forestry, Agriculture

Table 1. Sites where the study was conducted and its geographical location.

\begin{tabular}{ccccc}
\hline Municipality & Site/Location & Latitude $(\mathrm{N})$ & Length $(\mathrm{W})$ & Altitude $(\mathrm{m})$ \\
\hline Calkiní & Dzitbalché & $20^{\circ} 19^{\prime} 50.84^{\prime \prime}$ & $90^{\circ} 00^{\prime} 01.98^{\prime \prime}$ & 21 \\
Hecelchakán & Hecelchakán & $20^{\circ} 07^{\prime} 52.69^{\prime \prime}$ & $90^{\circ} 03^{\prime} 18.81^{\prime \prime}$ & 53 \\
Hopelchén & Bolonchén de Rejón & $19^{\circ} 56^{\prime} 55.13^{\prime \prime}$ & $89^{\circ} 45^{\prime} 12.37^{\prime \prime}$ & 124 \\
Hopelchén & Iturbide & $19^{\circ} 35^{\prime} 24.51^{\prime \prime}$ & $89^{\circ} 35^{\prime} 37.68^{\prime \prime}$ & 114 \\
Tenabo & Kanki & $19^{\circ} 58^{\prime} 54.84^{\prime \prime}$ & $90^{\circ} 06^{\prime} 47.26^{\prime \prime}$ & 47 \\
Campeche & Cayal & $19^{\circ} 45^{\prime} 09.46^{\prime \prime}$ & $90^{\circ} 09^{\prime} 52.46^{\prime \prime}$ & 31 \\
Campeche & Sitio Exp. Edzná & $19^{\circ} 36^{\prime} 33.45^{\prime \prime}$ & $90^{\circ} 13^{\prime} 15.45^{\prime \prime}$ & 21 \\
Campeche & San Luciano & $19^{\circ} 29^{\prime} 26.03^{\prime \prime}$ & $90^{\circ} 01^{\prime} 08.43^{\prime \prime}$ & 94 \\
Champotón & Valle de Quetzalcoatl & $19^{\circ} 13^{\prime} 03.72^{\prime \prime}$ & $90^{\circ} 12^{\prime} 35.75^{\prime \prime}$ & 41 \\
\hline
\end{tabular}


Table 2. Name of the genetic material according to its grain color.

\begin{tabular}{ccccccc}
\hline & \multicolumn{3}{c}{ White grain hybrids } & & & \multicolumn{2}{c}{ Yellow grain hybrids } \\
\cline { 1 - 2 } SB-309 & P3966W & DAS-2386 & H-516 & & $9107 \mathrm{Y}$ & RIO AMARILLO \\
DK-395 & SORENTO & H-520 & 9107 Y & & SP-525A & RIO DORADO \\
DK-393 & JC-25 & VAE-1105 & AS-1503 & & 2 2B688 & H-443A \\
DAS-2382 & LUCINO & JC-24 & DASUR 100 & & DK-7500 & TUNDRA \\
SP-500 & 9401W & RIO BLANCO & IMPARABLE & & P4226A & H-378A \\
DK-390 & DAS-2384 & SB-308M & H-515 & & IMPACTO & 9009 Y \\
P4082W & H-563 & H-431 & & & DK-7088 & SBA-410 \\
9209W & H-565 & SB-350 & & & DAS-3383 & SBA-404 \\
\hline
\end{tabular}

and Livestock Research (INIFAP) to produce seasonal maize in the state of Campeche were used [9]. The sowing dates for the years 2011 to 2016 were distributed in the range of July 5 to August 27; the most advanced date corresponded to the year 2011 and the most delayed corresponded to the year 2015. In the preparation of the soil, of all the options that were presented given the variability in localities and years, the one that predominated was the use of two traces (semi tracing-heavy and agricultural tracking), which was complemented with the application of herbicides before planting. The density of sowing that was used was 70 thousand seeds per hectare. In fertilization the dose of $100 \mathrm{~kg}$ of DAP per hectare was applied to the planting, plus $250 \mathrm{~kg}$ of Urea per hectare at 25 - 30 days of age of the plant. For the control of weeds the use of Nicosulfuron + Picloram + a hilling or weeding prevailed. In pest control there was a predominance of an application of emamectin benzoate. For the determination of the cost the harvest with combined machine was considered. Regarding the insurance, in order to obtain the total cost of the crop, the payment was considered without the government subsidy.

\subsection{Distribution of Treatments in the Field}

In this study they used the methods of demonstration plots and performance trials. The demonstration plots were Modules where different materials were validated at the same time. In them the "fringe arrangement" with a variable number of furrows was used, but of equal length (100 to $200 \mathrm{~m}$ ) according to the shape of the cooperating producer's plot. In these plots the yield was estimated from samples located in "five of golds", consisting of harvesting in each selected site, two furrows of eight meters in length. In the performance trials the arrangement was of random blocks with four repetitions, the groove width was invariably $80 \mathrm{~cm}$; the experimental plot was four furrows eight meters long. The yield in these tests was obtained by harvesting the useful plot, which were the two central rows.

\subsection{Study Variables}

The study variable was grain yield adjusted to $14 \%$ moisture [10]. 


\subsection{Procedure for the Harvest}

At the time of harvest, the plants and ears of the trial plot were counted, or in the sample (demonstration plot); with these data, the correction factor "ears per plant" $(\mathrm{FCm} / \mathrm{pl})$ was estimated. Only plants with complete competence were harvested. The sample of ears of corn was weighed to determine the total weight per plot/sample (Total weight). An average ear was selected in each case and weighed and shelled, calculating the grain percentage correction factor (FC\% gr) and the moisture content (FC 14\% hum) [11].

\subsection{Calculations}

In the cabinet the weight was determined by plot or sample adjusted to $14 \% \mathrm{hu}-$ midity, number of ears per plant, percentage of grain and the humidity correction factor. Subsequently, the area per plant and the harvested area were calculated. Finally, the weight per plot was transformed to Grain yield at $14 \%$ moisture in kilograms per hectare.

Weight per plot $(\mathrm{kg} \mathrm{14 \%} \mathrm{hum.})=($ Total weight $) \times(\mathrm{FCmz} /$ plant $) \times(\mathrm{FC} \%$ grain $) \times(\mathrm{FC} 14 \%$ hum. $)$ where FC14\% hum $=((100-$ field hum $) / 86)$.

Area per plant $=((12,500 \mathrm{~m} / 70,000$ plants $) \times 0.8 \mathrm{~m})=0.14286 \mathrm{~m}^{2} /$ plant where 12,500 is the amount of linear meters that there is in a hectare according to the furrow width of $0.8 \mathrm{~m}$ and 70,000 plants is the density of sowing.

Harvested area $=($ plants harvested on the plot or sample $) \times 0.14286 \mathrm{~m}^{2}$

Grain yield at $14 \%$ of hum. $\left(\mathrm{kg} \cdot \mathrm{ha}^{-1}\right)=(10,000) \times($ Weight per plot at $14 \%$ of hum.)/Harvested area

\subsection{Method Used for Statistical Analysis}

Three types of statistical analysis were performed: a regression analysis to determine the relationship between the amount of rainfall accumulated and the grain yield in the different years of study; an analysis under the completely random design, for the average grain yield of the study years; in addition to the analysis with the completely random design for hybrids according to their grain color [12].

\section{Results}

\subsection{Climate of the Study Area and the Corn Development Cycle}

In relation to the prevailing climate in the study area, Figure 1 shows that incident solar radiation registered a decrease from the beginning to the end of the crop cycle; starting with values of 419 and $440 \mathrm{w} / \mathrm{m}^{2}$ in July and August, respectively, and $305 \mathrm{w} / \mathrm{m}^{2}$ in December. On the other hand, the average temperature had a tendency similar to solar radiation, with values of $28^{\circ} \mathrm{C}$ and $27^{\circ} \mathrm{C}$ in July and August, respectively, and $23^{\circ} \mathrm{C}$ in December. On the other hand, rainfall data from the central region of the state of Campeche, in the years in which the 


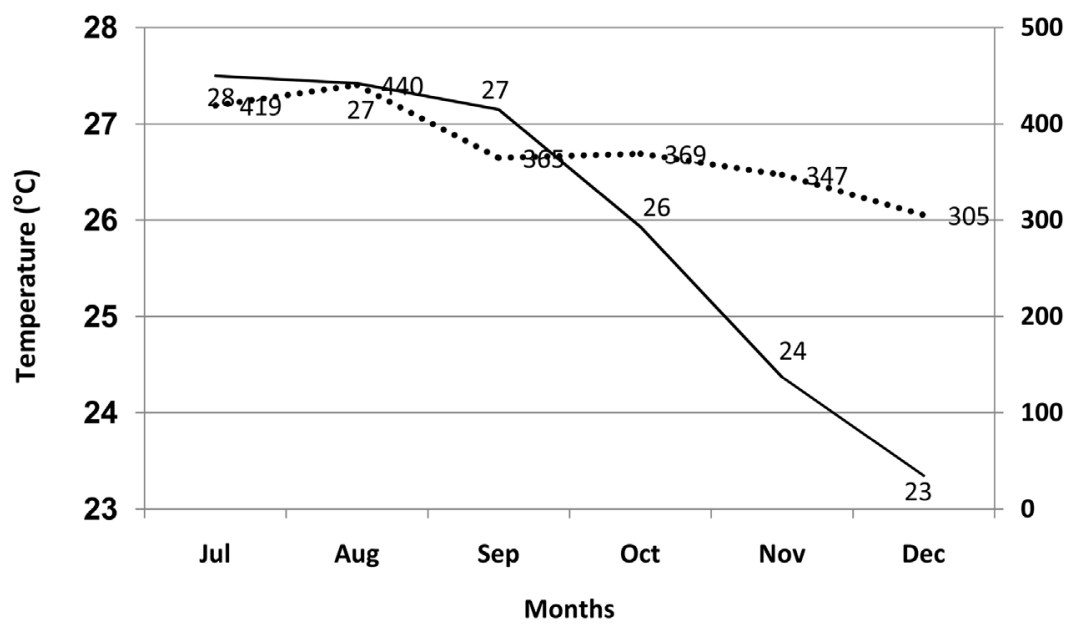

Figure 1. Behavior of solar radiation and temperature in the crop cycle.

study was carried out, indicated that the average accumulated precipitation between planting and the physiological maturity of the grain was $571 \mathrm{~mm}$, of which $314 \mathrm{~mm}$ occurred between sowing and flowering and $256 \mathrm{~mm}$ between flowering and the physiological maturity of the grain (Table 3). Also, in the aforementioned time interval, the year 2013 registered the most pronounced rainfall deficiency in the reproductive phase, with only $164 \mathrm{~mm}$; while 2012 and 2015 presented the lowest values in the vegetative phase, with 242 and $240 \mathrm{~mm}$, respectively. The relationship between total precipitation and yield is described in Figure 2, whose model was highly significant, indicating that yield values above $5200 \mathrm{~kg}$ are obtained with 530 to $660 \mathrm{~mm}$ of rain, since lower and higher values of rainfall reduce the Grain yield.

In this study it was also observed that the behavior of the crop followed a pattern that is schematized in Figure 3, where the stages of flowering, physiological maturity and grain drying, occurred on average at 55, 90 and 135 days, respectively. In this scheme, the most critical time interval of the plant was represented with red color in terms of humidity requirement.

\subsection{Variance Analysis of the Performance in the Years of Study}

This analysis was made taking the five years of study as treatments and the average performance of the materials that were evaluated in the same year, as repetitions. There was a significant difference high $(p=0.01)$ between the treatments (Table 4), and the DMS test $(\mathrm{p}=0.05)$ indicated that the years 2014 and 2012 were statistically equal, with 5500 and $5481 \mathrm{~kg} \cdot \mathrm{ha}^{-1}$ and higher in 2013 and 2015, which registered 4718 and $4646 \mathrm{~kg} \cdot \mathrm{ha}^{-1}$, respectively.

\subsection{Grain Yield}

The different varieties used in this study were grouped by their color of the grain to analyze separately the yield of 30 varieties of white grain and the 16 of yellow grain. An analysis of variance was used in which the treatments were the hybrids 
Table 3. Annual yield and rainfall distribution in two phases of plant development.

\begin{tabular}{ccccc}
\hline Year & $\begin{array}{c}\text { Total } \\
(\mathrm{mm})\end{array}$ & $\begin{array}{c}\text { Planting to } \\
\text { flowering }(\mathrm{mm})\end{array}$ & $\begin{array}{c}\text { Flowering to } \\
\text { physiological maturity }(\mathrm{mm})\end{array}$ & $\begin{array}{c}\text { Grain yield } \\
\left(\mathrm{kg} \cdot \mathrm{ha}^{-1}\right)\end{array}$ \\
\hline 2011 & 683 & 423 & 260 & 4967 \\
2012 & 604 & 242 & 362 & 5481 \\
2013 & 469 & 305 & 164 & 4718 \\
2014 & 597 & 362 & 235 & 5500 \\
2015 & 501 & 240 & 261 & 4646 \\
Average & $\mathbf{5 7 1}$ & 314 & $\mathbf{2 5 6}$ & $\mathbf{5 0 6 2}$ \\
\hline
\end{tabular}

Table 4. Variance analysis of the yield per year and the comparison of means test.

\begin{tabular}{cccccc}
\hline $\begin{array}{c}\text { Source of } \\
\text { variation }\end{array}$ & $\begin{array}{c}\text { Degrees of } \\
\text { freedom }\end{array}$ & Middle square & Year & $\begin{array}{c}\text { Grain yield } \\
\left(\mathrm{kg}^{\left.-\mathrm{ha}^{-1}\right)}\right.\end{array}$ & $\begin{array}{c}\mathrm{DMS} \\
(0.05)\end{array}$ \\
\hline Treatments & 4 & $13,992,143^{* *}$ & 2012 & 5481 & $\mathrm{a}$ \\
Error & 397 & $2,119,845$ & 2011 & 4967 & $\mathrm{a}$ \\
Total & 401 & & 2013 & 4718 & $\mathrm{~b}$ \\
& & 2015 & 4646 & $\mathrm{~b}$ \\
\hline
\end{tabular}

${ }^{*}$ significant difference $(\mathrm{p}=0.05),{ }^{*}$ highly significant difference $(\mathrm{p}=0.01)$.

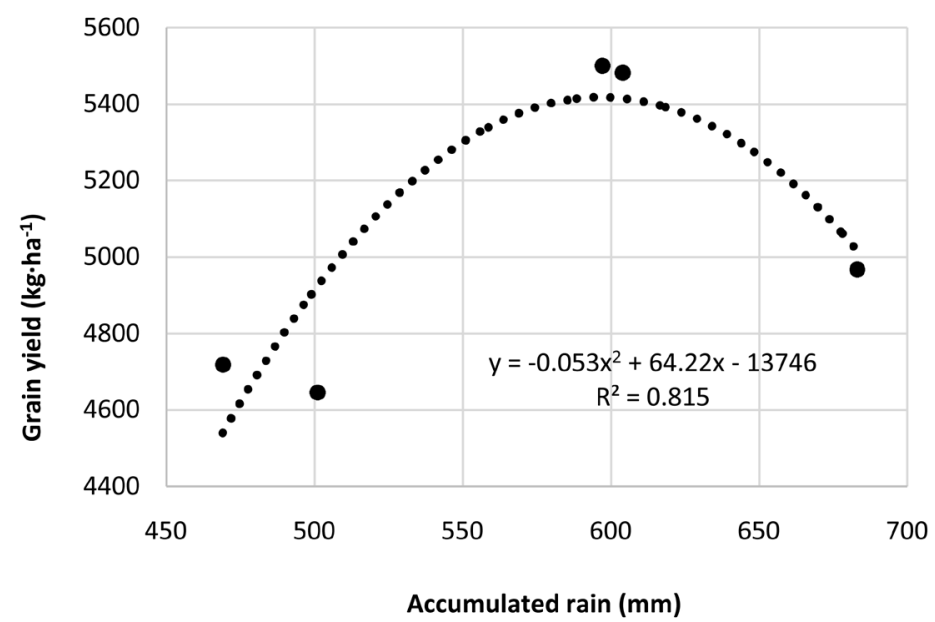

Figure 2. Relationship between the yield of grain and the amount of rainfall that occurred from sowing to physiological maturity.

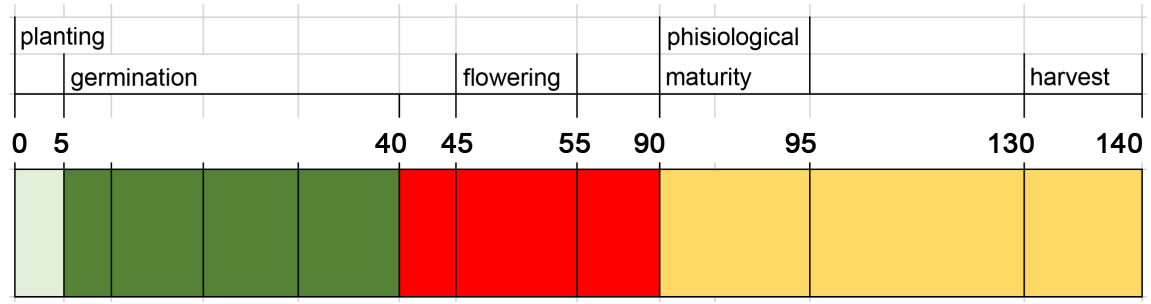

Figure 3. Number of days elapsed between sowing and the stages of flowering, physiological maturity and harvest in summer corn in Campeche, México. 
and the repetitions in the years and/or the localities where they were evaluated; these results are shown in (Table 5). With regard to white grain hybrids, the $\mathrm{F}$ test showed significant differences between treatments $(p=0.05)$, whereas in yellow grain hybrids the differences were highly significant $(\mathrm{p}=0.01)$. The above indicated at least one of the treatments in each classification behaved differently than the rest of them.

To determine which hybrids showed high and low yield, the separation test was carried out by the DMS method $(\mathrm{p}=0.05)$. The results indicated that SB-309, DK-395, DK-393 and DAS-2382 were the highest yield white-grain hybrids (Table 6); while 9107Y, SP-525A, 2B688, DK-7500 and P4226A were the yellow grain hybrids who excelled in this aspect (Table 7). On the other hand, white grain hybrids, DASUR 100, IMPARABLE and H-515 were the ones that showed the lowest yields; whereas, in those with yellow grain, those with the lowest yield were SBA-410 and SBA-404.

Table 5. Performance variance analysis between hybrids.

\begin{tabular}{ccccc}
\hline \multirow{2}{*}{ Source of variation } & \multicolumn{2}{c}{ White grain } & \multicolumn{2}{c}{ Yellow grain } \\
\cline { 2 - 5 } & Degrees of freedom & Middle square & Degrees of freedom & Middle square \\
\hline Tratamientos & 29 & $3,470,191^{*}$ & 15 & $6,549,781^{* *}$ \\
Error & 238 & $2,122,618$ & 106 & $1,698,916$ \\
Total & 267 & & 121 & \\
\hline
\end{tabular}

${ }^{*}$ significant difference $(\mathrm{p}=0.05),{ }^{*}$ highly significant difference $(\mathrm{p}=0.01)$.

Table 6. Comparison of means of white grain hybrids.

\begin{tabular}{|c|c|c|c|c|c|c|c|}
\hline Name & $\begin{array}{c}\text { Yield } \\
\left(\mathrm{kg} \cdot \mathrm{ha}^{-1}\right)\end{array}$ & $\begin{array}{c}\text { DMS }^{*} \\
(\mathrm{p}=0.05)\end{array}$ & Stratum & Name & $\begin{array}{c}\text { Yield } \\
\left(\mathrm{kg} \cdot \mathrm{ha}^{-1}\right)\end{array}$ & $\begin{array}{c}\text { DMS }^{*} \\
(p=0.05)\end{array}$ & Stratum \\
\hline SB-309 & 5874 & a & \multirow{17}{*}{ 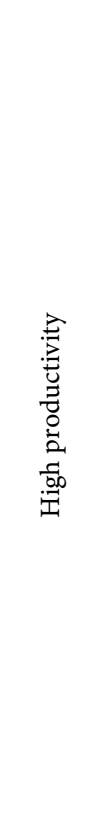 } & DAS-2384 & 4973 & abcd & \multirow{17}{*}{ 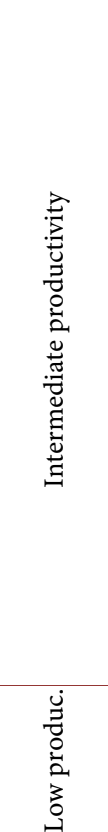 } \\
\hline DK-395 & 5863 & $\mathrm{a}$ & & H-563 & 4932 & abcd & \\
\hline DK-393 & 5763 & $a b$ & & H-565 & 4864 & abcd & \\
\hline DAS-2382 & 5675 & $a b$ & & DAS-2386 & 4847 & abcd & \\
\hline SP-500 & 5509 & $a b c$ & & H-520 & 4775 & abcd & \\
\hline DK-390 & 5494 & $\mathrm{abc}$ & & VAE-1105 & 4743 & abcd & \\
\hline P4082W & 5446 & $\mathrm{abc}$ & & JC-24 & 4721 & abcd & \\
\hline $9209 \mathrm{~W}$ & 5364 & $\mathrm{abc}$ & & RIO BLANCO & 4709 & abcd & \\
\hline P3966W & 5322 & $\mathrm{abc}$ & & SB-308M & 4569 & abcd & \\
\hline SORENTO & 5309 & $a b c$ & & H-431 & 4529 & abcd & \\
\hline JC-25 & 5217 & $a b c$ & & SB-350 & 4514 & abcd & \\
\hline LUCINO & 5162 & $a b c$ & & H-516 & 4469 & abcd & \\
\hline \multirow[t]{5}{*}{$9401 \mathrm{~W}$} & 5143 & $a b c$ & & $9107 \mathrm{Y}$ & 4106 & abcd & \\
\hline & & & & AS-1503 & 4027 & bcd & \\
\hline & & & & DASUR 100 & 3789 & $\mathrm{~cd}$ & \\
\hline & & & & IMPARABLE & 3761 & $\mathrm{~cd}$ & \\
\hline & & & & H-515 & 3222 & d & \\
\hline
\end{tabular}

*Significant minimum difference. 
Table 7. Comparison of means of yellow grain hybrids.

\begin{tabular}{|c|c|c|c|c|c|c|c|}
\hline Name & $\begin{array}{c}\text { Yield } \\
\left(\mathrm{kg}^{2} \cdot \mathrm{ha}^{-1}\right)\end{array}$ & $\begin{array}{c}\mathrm{DMS}^{*} \\
(\mathrm{p}=0.05)\end{array}$ & Stratum & Name & $\begin{array}{c}\text { Yield } \\
\left(\mathrm{kg} \cdot \mathrm{ha}^{-1}\right)\end{array}$ & $\begin{array}{c}\text { DMS }^{*} \\
(\mathrm{p}=0.05)\end{array}$ & Stratum \\
\hline $9107 \mathrm{Y}$ & 5885 & a & \multirow{8}{*}{ 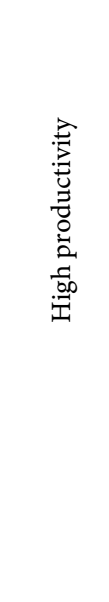 } & DAS-3383 & 4934 & $a b c$ & \\
\hline SP-525A & 5642 & $\mathrm{ab}$ & & RIO AMARILLO & 4767 & $a b c$ & 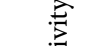 \\
\hline 2B688 & 5469 & $\mathrm{ab}$ & & RIO DORADO & 4676 & $a b c$ & 节 \\
\hline DK-7500 & 5432 & $\mathrm{ab}$ & & $\mathrm{H}-443 \mathrm{~A}$ & 4619 & $a b c$ & 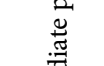 \\
\hline P4226A & 5390 & $\mathrm{ab}$ & & TUNDRA & 4563 & $a b c$ & 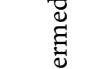 \\
\hline IMPACTO & 5248 & $a b c$ & & $\mathrm{H}-378 \mathrm{~A}$ & 4457 & $a b c$ & $\stackrel{\Xi}{\Xi}$ \\
\hline \multirow[t]{2}{*}{ DK-7088 } & 5012 & $a b c$ & & $9009 \mathrm{Y}$ & 4070 & $\mathrm{bc}$ & \\
\hline & & & & $\begin{array}{l}\text { SBA-410 } \\
\text { SBA-404 }\end{array}$ & $\begin{array}{l}3661 \\
2017\end{array}$ & $\begin{array}{l}\mathrm{c} \\
\mathrm{d}\end{array}$ & $\begin{array}{l}\dot{U} \\
\text { ठ0 } \\
0 \\
0 \\
3 \\
0 \\
0\end{array}$ \\
\hline
\end{tabular}

${ }^{\star}$ Significant minimum difference.

\subsection{Costs of the Technological Package}

The total cost to grow one hectare of corn at prices updated to 2018 amounted to $\$ 10,961.00$, and for the purposes of financial analysis this information was summarized in Table 8, which presents the specific cost for the different components included in the Technology Package recommended. As can be seen, fertilization, sowing and soil preparation are the items with the highest value; this is due to the high cost of fertilizers, seed and fuels.

\subsection{Financial Analysis}

The financial analysis was carried out separately for hybrids of white and yellow cattle (Table 9), considering the groups of high, intermediate and low productivity. The Income (I), the Benefit (B), the Benefit-cost relationship (B/C), as well as the equilibrium point (PE) were calculated (Table 9) [13] [14] [15]. The average price of one ton of grain was estimated at $\$ 3300.00$ for both types of grain. The sources of information were the grain collectors, and the Services Agency for the Marketing and Development of Agricultural Markets of the city of San Francisco de Campeche [16]. The values in the benefit per hectare in the white grain hybrids were from 7219 to 609 pesos; while in the yellow grain from 7410 to -916 pesos. Due to the above, the profitability was positive in the intermediate and high productivity strata in both types of grain, with gains of 35 to 66 cents per peso invested in the white grain and from 43 to 68 cents in the yellow grain [17]. In the low productivity stratum, profitability was negative for yellow grain hybrids and had low values in white grain hybrids. Finally, regardless of the color of the grain and the stratum, the yield at the equilibrium point was $3321 \mathrm{~kg} \cdot \mathrm{ha}^{-1}$. 
Table 8. Distribution of cultivation costs.

\begin{tabular}{cc}
\hline Concept & Total Cost (\$) \\
\hline Soil preparation & 1672.00 \\
Planting & 2612.00 \\
Fertilization & 2770.00 \\
Weed control & 967.00 \\
Pest control & 390.00 \\
Harvest & 750.00 \\
Assurance & $1800.00^{*}$ \\
Costo total & $10,961.00$ \\
\hline
\end{tabular}

*Does not include the government subsidy.

Table 9. Financial analysis of the two types of grain according to their productivity stratum.

\begin{tabular}{ccccccc}
\hline & \multicolumn{3}{c}{ White corn } & \multicolumn{3}{c}{ Yellow corn } \\
\cline { 2 - 6 } Concepts & \multicolumn{3}{c}{ Productivity strata } & \multicolumn{2}{c}{ Productivity strata } \\
\cline { 2 - 7 } & High & Intermediate & Low & High & Intermediate & Low \\
\hline Grain yield $\left({\left.\mathrm{kg} \cdot \mathrm{ha}^{-1}\right)}\right.$ & 5.509 & 4.500 & 3.506 & 5.567 & 4.735 & 3.044 \\
Cost $\left(\$ \mathrm{ha}^{-1}\right)$ & 10,961 & 10,961 & 10,961 & 10,961 & 10,961 & 10,961 \\
Price per ton $(\$)$ & 3300 & 3300 & 3300 & 3300 & 3300 & 3300 \\
Income $\left(\$ \mathrm{ha}^{-1}\right)$ & 18,180 & 14,850 & 11,570 & 18,371 & 15,626 & 10,045 \\
Benefit $\left(\$ \mathrm{ha}^{-1}\right)$ & 7219 & 3889 & 609 & 7410 & 4665 & -916 \\
Ratio B/C $(\$)$ & 0.66 & 0.35 & 0.06 & 0.68 & 0.43 & -0.08 \\
Equilibrium point $\left(\mathrm{kg} \cdot \mathrm{ha}^{-1}\right)$ & 3321 & 3321 & 3321 & 3321 & 3321 & 3321 \\
\hline
\end{tabular}

\section{Discussion}

Producers use the July to December interval to grow corn because it covers the rainy season of the year, where the water requirement of the plant could be met; However, during the years that this study lasted, an average of $571 \mathrm{~mm}$ of rain per year accumulates in this time interval, from sowing to the physiological maturity of the grain, so it seems that there is a water deficit that affects the performance. The series of stages of development that occur between flowering and physiological maturity are characterized by being highly sensitive to moisture stress; the accumulation of dry matter in the grain, through the translocation of assimilates towards it, are processes that define the final yield. The poor distribution of rainfall is another factor that affects yield, since as observed, the crop receives less moisture from flowering at physiological maturity $(256 \mathrm{~mm})$, and this sense, one of the most critical years was 2013, presented (164 mm). In contrast, 2012 was an exceptional year, because although it only accumulated 242 $\mathrm{mm}$ from sowing to flowering, in the interval of flowering at physiological maturity it accumulated $362 \mathrm{~mm}$, which favored yield [18] [19] [20] [21]. 
The temperature is intimately linked to the incident solar radiation and therefore both show high values that extend from the beginning of the sowing of the corn until the physiological maturity of the grain arrives and after that they have a slight decrease. According to [18], the average temperature higher than $26^{\circ} \mathrm{C}$ is above the optimum requirement for crop development, therefore, it affects the yield since it limits the development of the plant, shortening the time between the phenological stages and accelerating its development [22]; This led to the great majority of hybrids exhibiting a very short life cycle, which ultimately affects yield because it limits the processing of assimilates and their subsequent translocation to the grain. The fact that there is a descending behavior of the temperature in the months of November and December is no longer beneficial for the yield since the most critical stages in the development of the plant were left behind [23] [24]. In this region of the country some years the rains tend to be delayed and alter the normal sowing calendar. Because of this, this activity is usually out of phase for a month and therefore the amount of rain received by the crop is lower, this being one of the causes of poor performance as is the case in 2015, whose yield was $3433 \mathrm{~kg} \cdot \mathrm{ha}^{-1}$ because it had planting dates that were mainly located in the month of August [25]. In a correlation between the yield and the planting date, it was observed that there was an increase in the yield in the three planting dates corresponding to the month of July; and later there was a decrease of this, in the planting dates corresponding to the three tens of August (Figure 4).

The results obtained were combined through the statistical analysis of grain yield and three strata were formed that were denominated as low, intermediate and high productivity (Table 6 and Table 7). Then the observations from the cost analysis of the applied technology were used, with which some comparisons were made using the parameter known as the equilibrium point, which indicates the minimum yield per unit area, which the producer needs to obtain, to cover

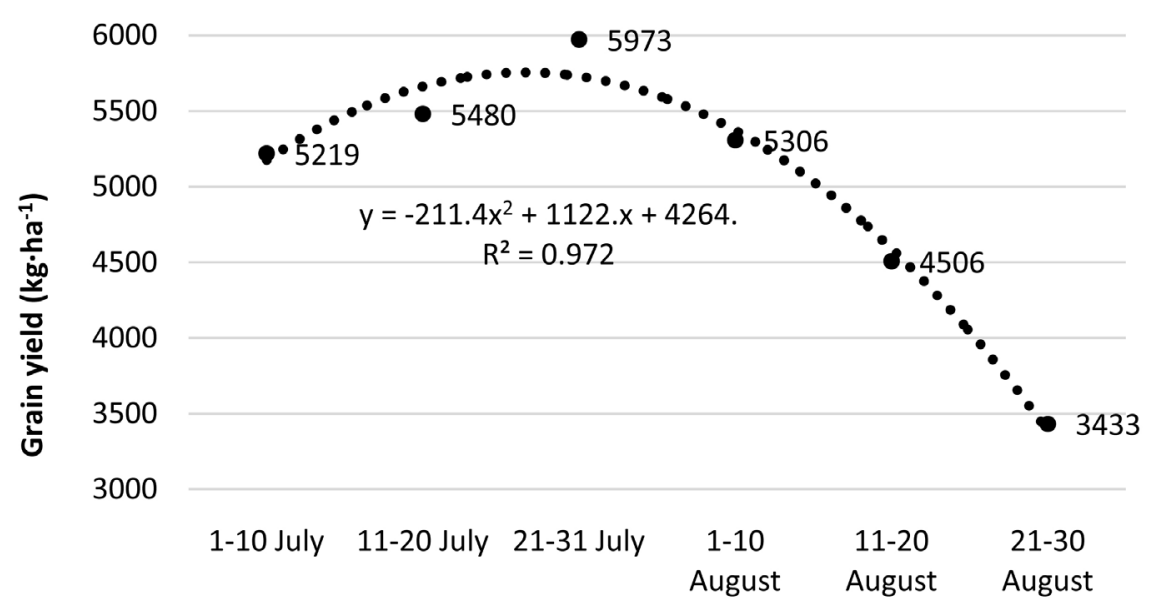

Interval of planting dates

Figure 4. Trend of grain yield in relation to the planting date. 
the cost of cultivation [26]. The average yield of the low productivity stratum in white grain corn was $3450 \mathrm{~kg} \cdot \mathrm{ha}^{-1}$, while in the yellow grain it was $2800 \mathrm{~kg} \cdot \mathrm{ha}^{-1}$. Comparing the average of both $\left(3125 \mathrm{~kg} \cdot \mathrm{ha}^{-1}\right)$ with the value obtained in the parameter known as the equilibrium point (Table 9), which is equivalent to 3321 $\mathrm{kg}$ ha-1, the hybrids contained in this stratum have yields inferior to the latter, and they do not report profits to the producer, which limits their use. With respect to the intermediate productivity stratum, 14 hybrids of white grain and seven of yellow grain were found and their average yield was higher in 1080 $\mathrm{kg} \cdot \mathrm{ha}^{-1}$ at the value of $3321 \mathrm{~kg} \cdot \mathrm{ha}^{-1}$, reported at the equilibrium point. From this it can be deduced that the hybrids that are grouped in the intermediate productivity stratum already provide some profit to the producer and because of this they constitute a viable option to use. On the other hand, white grain hybrids, SB-309, DK-395, DK-393, DAS-2382, SP-500, DK-390, P4082W, 9209W, P3966W, SORENTO, JC-25, LUCINO, and 9401W; as well as the hybrids of yellow grain, 9107Y, SP-525A, 2B688, DK-7500, P4226A and IMPACT, which made up the high-productivity stratum, exceeded by $2100 \mathrm{~kg}$ the yield obtained at the so-called equilibrium point, equivalent to $3321 \mathrm{~kg} \cdot h \mathrm{a}^{-1}$, which allowed to determine that these are the most recommended hybrids for producers according to the technological management of the crop that is currently done, since these are the hybrids that can provide the highest profitability. Among the reasons why some hybrids showed low grain yield are their ability to adapt to the environment of scarce and poorly distributed precipitation, low soil moisture retention capacity; In addition to the susceptibility presented by the hybrids, to the pathogens causing diseases such as "Corn stunting" (Spiroplasma kunkelii), "Curvularia" (Curvularia lunata) and Leaf blight (Helminthosporium turcicum), mentioned by [27] and [28], which were identified during the course of the investigation (unpublished data). Therefore, our consideration is that the hybrids of the low productivity stratum could not be used without a strong adjustment to the applied technology; for which it should start by conducting research to evaluate the impact on the performance, chemical control of diseases such as those already mentioned and/or the use of some method for the control of insects vectors of "corn stunting". On the other hand, the hybrids that make up the intermediate productivity stratum present the possibility of offering a positive response to the application of technology with a tendency to reduce the cost of cultivation [29], which is considered to be a priority to investigate if desired use some of them for planting. Among the technological options that need to be investigated would be the lowest doses of fertilizer, fewer plants per hectare than the one used in this study, a different soil preparation and crop rotations. Finally, the hybrids located in the high productivity stratum should move to a research stage where a detailed characterization of the genotype-environment interaction is carried out, which determines its orientation towards favorable or unfavorable climate, soil and quality environments, the handling of the inputs, since in this way a better response could be obtained from them. 


\section{Conclusions}

Elements of climate, technology, production costs and grain yield of 46 corn hybrids were analyzed. From this, it was determined that there are 41 materials, 27 of white grain and 14 of yellow grain, which can be considered as viable options to make profitable production in this entity of the Mexican Republic.

The sensitivity analysis indicated that 13 white grain hybrids and seven yellow grain hybrids exhibited the highest productivity with the technology currently used. These hybrids could henceforth be integrated into a study of the genotype-environment interaction to locate each one in the place where it is possible to make better use of their genetic potential.

Current technology should be adjusted to increase the profitability of 21 hybrids that were located in the intermediate productivity stratum. For this, it will be necessary to carry out research aimed at reducing the cost of production.

\section{Conflicts of Interest}

The authors declare that they have no conflicts of interest with respect to the publication of this document.

\section{References}

[1] SAGARPA (2018) Maíz blanco y amarillo mexicano. Secretaría de Agricultura, Ganadería, Desarrollo Rural, Pesca y Alimentación, México. Planeación agrícola 2017-2030. 22 p.

https://www.gob.mx/cms/uploads/attachment/file/256429/B_sico-a_z_Grano_Blanc o_y_Amarillo.pdf

[2] Uzcanga, P.N.G., Cano, G.A.J., Medina, M.J. and Espinoza, A.J.J. (2015) Caracterización de los productores de maíz de temporal en el estado de Campeche, México. Revista mexicana de agronegocios, 36, 1295-1305.

[3] FAO-UNESCO (1976) Mapa mundial de suelos 1:5000000. Vol. III. México y América Central. Organización de las Naciones Unidas para la Agricultura y la Alimentación-Organización de las Naciones Unidas para la Educación. Paris Francia. Pág. 24-51. http://www.fao.org/docrep/019/as358s/as358s.pdf

[4] INEGI (2017) Anuario estadístico y geográfico de Campeche 2017. https://www.datatur.sectur.gob.mx/ITxEF_Docs/CAM_ANUARIO_PDF.pdf

[5] Medina, M.J. and Villalobos, G.A. (2009) El riego de auxilio, factor para asegurar el rendimiento en zonas de alto potencial para producir maíz en Campeche. Ficha de tecnología validada. INIFAP. CIR-Sureste. Campo Experimental Edzná. 2 p.

[6] Martínez, A. and González, C. (2000) Evaluación de variedades de maíz. Resultados de cuatro años. Servicio Regional de Investigación y Desarrollo Agroalimentario. Principado de Asturias. España. 4 p. http://ria.asturias.es/RIA/bitstream/123456789/1704/1/varmaiz.pdf

[7] Yan, W., Hunt, L.A., Sheng, Q. and Szlavnics, Z. (2000) Cultivar Evaluation and Mega Environment Investigation Based on the GGE Biplot. Crop Science, 40, 597-605. https://doi.org/10.2135/cropsci2000.403597x

[8] Biasutti, C.A. and Balzarini, M. (2012) Estimación del comportamiento de híbridos de maíz mediante modelos mixtos. Agriscientia, 29, 59-68. 
https://www.researchgate.net/publication/260771408_Estimacion_del_comportami ento_de_hibridos_de_maiz_mediante_modelos_mixtos/download

[9] INIFAP (2017) Instituto Nacional de Investigaciones Forestales, Agrícolas y Pecuarias. Agenda Técnica Agrícola de Campeche. 19-22.

http://www.inifap.gob.mx/Documents/inicio/Agendas_Tec/2017/Agenda\%20T\%C3 \%A9cnica\%20Campeche\%20OK.pdf

[10] Pérez, C.J.P. (2001) Metodología para la evaluación de la cosecha de maíz en parcelas comerciales. INIFAP. CIRCE. Campo Experimental Pachuca. Desplegable para productores No. 5 .

http://www.inifap.gob.mx/circe/Documents/publihid/Evaluacion\%20cosechas\%20d e\%20maiz.pdf

[11] Martínez, M.M.R. (2010) Proyecto especial de maíz de alto rendimiento. Informe de evaluación y seguimiento. Secretaría de Agricultura, desarrollo Rural, Pesca y Alimentación. México. 143 p.

https://docplayer.es/7083654-Proyecto-especial-de-produccion-de-maiz-de-alto-ren dimiento-proemar-2009.html

[12] Little, T.M. and Hills, F.J. (1985) Métodos Estadísticos para la investigación en la agricultura. Editorial Trillas. S.A. de C.V. México. 53-57.

[13] INIFAP (1994) Memoria del curso de capacitación en metodologías para la evaluación financiera y económica de las tecnologías agropecuarias y forestales. Programa de economía del INIFAP. D. F., México. 201 p.

[14] Medina, M.J. (2006) Cambios en las propiedades del suelo y productividad de los sistemas de maíz bajo temporal, mango bajo riego y pradera, en Luvisoles del Estado de Campeche. Tesis de Doctor en Ciencias. Colegio de Postgraduados. Montecillo, Edo de México. 226 p.

[15] Nápoles, H.N. (2007) Evaluación financiera del cultivo de maíz con labranza de conservación. Tesis de Ingeniero Agrónomo. Universidad Autónoma Chapingo. Texcoco Edo. de México. 82 p.

[16] ASERCA (2016) Precios del maíz blanco y amarillo en 2015 (comunicación personal). Agencia de Servicios a la Comercialización y Desarrollo de Mercados Agropecuarios. Delegación en la ciudad de San Francisco de Campeche.

[17] Rosseti, P.J. (1985) Introducción a la Economía Enfoque Latinoamericano. Séptima Edición. Industria Editorial Mexicana. D. F., México. 42-80.

[18] Ruiz, C.J.A., Medina, G.G., Ortiz, T.C., Martínez, P.R., González, A.I.J., Flores, L.H.E. and Byerly, M.K.F. (1999) Requerimientos agroecológicos de cultivos. INIFAP. Libro técnico. 324 p.

http://www.inifapcirpac.gob.mx/publicaciones_nuevas/Requerimientos\%20Agroec \%20de\%20Cultivos\%202da\%20Edici\%F3n.pdf

[19] Pimentel, D., Berger, B., Filiberto, D., Newton, M., Wolfe, B., Karabinakis, E., Clark, S., Poon, E., Abbett, E. and Nandagopal, S. (2004) Water Resources: Agricultural and Environmental Issues. BioScience, 54, 909-918. https://doi.org/10.1641/0006-3568(2004)054[0909:WRAAEI]2.0.CO;2 https://academic.oup.com/bioscience/article-abstract/54/10/909/230205

[20] Ojeda, B.W., Sifuentes, I.E. and Unland, W.H. (2006) Programación integral del riego en maíz en el norte de Sinaloa, México. Agrociencia, 40, 13-25.

[21] Doria, J. (2010) Generalidades sobre las semillas: Su producción, conservación y almacenamiento. Cultivos Tropicales, 31, 74-85.

[22] Lafitte, H.R. (2001) Fisiología del maíz tropical. En: Maíz en los trópicos. Organiza- 
ción de las Naciones Unidas, Roma, Italia. http://www.fao.org/3/X7650S/x7650s00.htm

[23] Rincón, T.J.A., Castro, N.S., López, S.J.A., Briones, E.F., Ortiz, C.J. and Huerta, A.J. (2008) Modificación de características agronómicas en maíz tropical por efecto de selección bajo estrés hídrico. Revista Fitotecnia Mexicana, 31, 81-84.

[24] Ramírez, D.J.L., Wong, P.J.J., Ruiz, C.J.A. and Chuela, B.M. (2010) Cambio de fecha de siembra del maíz en Culiacán, Sinaloa, México. Revista Fitotecnia Mexicana, 33, 61-68.

http://www.scielo.org.mx/scielo.php?script=sci_arttext\&pid=S0187-7380201000010 $\underline{0010}$

[25] Balzarini, M., Bruno, C. and Arroyo, A. (2014) Análisis de ensayos agrícolas multi-ambientales. Ejemplos con Info-Gen. Estadística y Biometría. Facultad de Ciencias Agropecuarias. Universidad Nacional de Córdoba, Argentina, 141 p.

[26] Retes, L.R., Moreno, M.S., Denogean, B., Francisco, G., Rivera, M.M. and Ibarra, F.F. (2015) Análisis de rentabilidad del cultivo de algodón en sonora. Revista Mexicana de Agronegocios, 36, 1156-1166.

http://www.redalyc.org/pdf/141/14132408002.pdf

[27] CIMMYT (2004) Programa de Maíz del Centro Internacional de Mejoramiento de Maíz y Trigo. Enfermedades del maíz: Una guía para su identificación en el campo. Cuarta edición. México, D.F. 118 p.

[28] Ríos, H.E.N., Ochoa, F.Y.M., Cerna, C.H., Landeros, F.J., Cepeda, S.M. and Rodríguez, G.R. (2017) Hongos asociados a la mancha de asfalto en el cultivo de maíz en México. Revista Mexicana de Ciencias Agrícolas, 8, 457-462.

https://doi.org/10.29312/remexca.v8i2.65

[29] Orona, C.F., Medina, M.J., Tucuch, C.F.M., Soto, J.M. and Almeyda, L.J.H. (2013) Parámetros de estabilidad en rendimiento y adaptabilidad de 25 genotipos de arroz en Campeche, México. FYTON ISSN, 82, 255-261.

http://www.revistaphyton.fund-romuloraggio.org.ar/vol82/ORONA_CASTRO.pdf 